White, A. M., G. L. Tarbill, B. Wilkerson, and R. Siegel. 2019. Few detections of Black-backed Woodpeckers (Picoides arcticus) in extreme wildfires in the Sierra Nevada. Avian Conservation and Ecology 14(1):17. https://doi.org/10.5751/ACE-01375-140117

Copyright (C) 2019 by the author(s). Published here under license by the Resilience Alliance.

Research Paper

\title{
Few detections of Black-backed Woodpeckers (Picoides arcticus) in extreme wildfires in the Sierra Nevada
}

\author{
Angela M. White ${ }^{1}$, Gina L. Tarbill ${ }^{1,2,3}$, Robert L. Wilkerson ${ }^{4}$ and Rodney B. Siegel ${ }^{5}$ \\ ${ }^{1}$ USDA Forest Service, Pacific Southwest Research Station, ${ }^{2}$ Oak Ridge Institute for Science and Education, ${ }^{3}$ University of \\ California, Davis, ${ }^{4}$ Institute for Bird Populations, ${ }^{5}$ The Institute for Bird Populations
}

\begin{abstract}
Extreme wildfires in coniferous forests produce large areas of dead trees (snags) that are expected to provide much needed habitat for the Black-backed Woodpecker, a postfire associate. In an attempt to better understand extreme fire effects (including increasing fire size and decreasing diversity of fire effects), we monitored Black-backed Woodpeckers during the 2014 and 2015 breeding seasons following two wildfires (the $2013 \mathrm{Rim}$ and $2014 \mathrm{King}$ fire) that burned in the Sierra Nevada, USA under extreme fire conditions. Despite an extensive sampling effort including 1025 broadcast surveys and targeted nest searching over 2040 ha of habitat typically used for nesting, we detected few Black-backed Woodpeckers. Positive detections of Black-backed Woodpeckers at broadcast points were positively associated with increases in the percent of surrounding forest that burned at high-severity and with the distance to the fire perimeter, indicating that the severity and scale of the fire per se did not affect use by Black-backed woodpeckers within the fire area. However, we suggest that the timing of these fires late in the fire season may have limited colonization of prey resources, leading to more limited use of these fires by Black-backed Woodpeckers.
\end{abstract}

\section{Faible détection de Pics à dos noir (Picoides arcticus) dans des secteurs extrêmement brûlés de la Sierra Nevada}

RÉSUMÉ. Les incendies extrêmes qui surviennent dans les forêts conifériennes produisent de vastes étendues d'arbres morts (chicots), desquelles on s'attend à ce qu'elles fournissent de l'habitat dont a grandement besoin le Pic à dos noir, une espèce associée aux brûlis. Afin de mieux comprendre les effets des incendies de forêts extrêmes (y compris l'augmentation de la superficie des incendies et la diminution de la diversité de leurs effets), nous avons suivi des Pics à dos noir durant les saisons de nidification 2014 et 2015 , suite à deux incendies (l'incendie Rim en 2013 et le King en 2014) qui ont fait rage dans la Sierra Nevada, aux États-Unis, dans des conditions de feu extrêmes. Malgré un effort d'échantillonnage intense comprenant 1025 relevés assistés d'enregistrements de chants et des recherches ciblées de nids dans 2040 ha d'habitat typiquement utilisé pour la nidification, nous n'avons détecté que peu de Pics à dos noir. Les pics détectés aux points d'écoute étaient positivement associés avec la hausse du pourcentage de forêts environnantes ayant brûlé de façon sévère et la distance au périmètre de l'incendie, indiquant que la sévérité et la superficie de l'incendie comme telles n'affectaient pas l'utilisation par le Pic à dos noir du secteur incendié. Toutefois, nous pensons que le déclenchement de ces incendies tard dans la saison des feux a sans doute limité la colonisation par les proies, menant à une utilisation plus restreinte de ces secteurs incendiés par les Pics à dos noir.

Key Words: Black-backed Woodpecker; colonization; dispersal; extreme fire; habitat specialist; metapopulation; prey dynamics; woodboring beetles

\section{INTRODUCTION}

Dry coniferous forests of the western United States are now experiencing increasing wildfire activity and severity due to both an accumulation of forest fuels and changing climatic conditions (Westerling et al. 2006, Dennison et al. 2014, Safford and Stevens 2017, Stevens et al. 2017). Wildfires are now burning hotter, longer, and larger than fires previously recorded in the region (Westerling et al. 2006, Miller et al. 2009), resulting in extreme fires with enormous and lasting human, ecological, and economic effects because of their size, severity, and location (Williams 2013, Stephens et al. 2014). Although the large patch size and continuous areas of dead trees in these severe fires may have detrimental consequences for ecosystem processes such as soil stabilization, nutrient cycling, seed dispersal, and carbon sequestration (Adams 2013, Long et al. 2014), such areas would seem to create a plethora of habitat for the Black-backed Woodpecker (Picoides arcticus) and a myriad of other severe-fire dependent plant and animal species (Hutto 2008). The Blackbacked Woodpecker inhabits boreal and montane forests of North America where it is strongly associated with forest disturbances that result in large-scale tree mortality, such as highseverity fire (Saab and Powell 2005, Hutto 2008, Nappi and Drapeau 2009, Saracco et al. 2011) and, to a lesser degree, bark beetle outbreaks (Rota et al. 2014a, b), although it is also found in undisturbed forests (Tremblay et al. 2016).

With its chisel-like beak and strong excavation ability, the Blackbacked Woodpecker creates nest cavities in recently dead trees 
(Saab et al. 2007) and forages on saproxylic insects, primarily the larvae of beetles in the families Cerambycidae and Buprestidae (Villard 1994, Murphy and Lehnhausen 1998), which are dependent on dead or decaying wood to complete their life cycles. The amount and decomposition rate of dead and dying trees thus influences habitat availability for the Black-backed Woodpecker (Nappi et al. 2010). Tremblay et al. (2010) found that Blackbacked Woodpeckers can subsist in unburned forests provided there is a sufficient and continuous production of dead and dying trees. In the boreal forests of Canada, which tend to experience large, infrequent stand-replacing events (Payette 1992), most trees are killed in a single pulse, resulting in largely synchronized tree mortality and subsequent decay rates. In such fires, Black-backed Woodpecker populations are irruptive and individuals tend to occupy these fires for short periods of time (as little as two years) before dispersing to new habitat patches (Nappi and Drapeau 2009). When forest fires burn at lower intensity, this results in smaller patches of fire-killed trees within the fire matrix (Safford and Stevens 2017, Stevens et al. 2017, Steel et al. 2018) that die nonsynchronously, allowing populations of Black-backed Woodpeckers to be more sedentary and subsist in individual fires for up to 10 years, though frequently less (Saracco et al. 2011).

The southernmost extent of the range of the Black-backed Woodpecker is in the Sierra Nevada Mountains of California (Siegel et al. 2018). In the past century, logging, grazing, and fire suppression have altered the fire regime in much of the Sierra Nevada such that the area of forest that burned annually decreased by an order of magnitude (North et al. 2012). In addition, when fires did burn, dead and dying trees were commonly salvage logged, reducing habitat for the Black-backed Woodpecker (Hutto 2006, Saab et al. 2007). However, the paucity of post-fire habitat may be changing: climate change coupled with artificially high fuel loads and drought have resulted in some of the most extreme fire conditions in the Sierra Nevada on record (Westerling et al. 2006, Stephens et al. 2014) that burn with a higher proportion of stand-replacing effects than historically experienced for this region (Miller et al. 2009, Steel et al. 2015, Safford and Stevens 2017, Stevens et al. 2017, Steel et al. 2018). Although the resulting fires may provide an abundance of dead trees indicative of Black-backed Woodpecker habitat, the scale and homogeneity of fire effects may alter habitat quality in unpredictable ways. For instance, distance to unburned forest may be much higher in these fires, which may be important to Blackbacked Woodpecker fledglings that select habitat with higher proportion of live trees than adult birds (Stillman et al. 2019).

We investigated the initial colonization by Black-backed Woodpeckers in two extreme wildfires that resulted in uncharacteristically large tracts of burned forest (Lydersen et al. 2014, Jones et al. 2016). Specifically, we were interested in whether the spatial configuration of high-severity patches within the fire matrix influenced presence and nesting behavior of Black-backed Woodpeckers. This research not only has important implications for Black-backed Woodpeckers and other species that depend on snags (Raphael and White 1984, Nappi et al. 2003, Hutto 2006), but also raises important questions about how highly adapted species may respond to a changing landscape of fire that includes homogenization of fire effects.

\section{METHODS}

\section{Study area}

We conducted our study throughout U.S. Forest Service lands that could be safely accessed within the perimeter of the Rim and King fires. The Rim Fire burned 104,131 ha in the Stanislaus National Forest, Yosemite National Park, and adjacent private lands between 13 August and 23 October, 2013. The King fire burned 39,544 ha in the Eldorado National Forest and adjacent private lands from 13 September to 9 October 2014 (Fig. 1). Both the Rim and the King fires burned ponderosa pine and mixed conifer forests under extreme weather conditions leading to large patches of dead trees (see Lydersen et al. 2014, Jones et al. 2016). Common tree species in both fires included white fir (Abies concolor), Douglas-fir (Pseudotsuga menziesii), ponderosa pine (Pinus ponderosa), sugar pine (P. lambertiana), incense-cedar (Calocedrus decurrens), and California black oak (Quercus kelloggii).

Fig. 1. Location and extent of fires that burned on US Forest Service lands (shown in green) on the Tahoe, Lake Tahoe Basin, Eldorado, and Stanislaus National Forests in the central Sierra Nevada Mountains of California, USA from 2000-2014. The delineation and name of US Forest Service lands are shown in green. Fires older than 10 years are unlikely to support Blackbacked Woodpecker populations. We surveyed for Blackbacked Woodpeckers in the Rim fire (2013) in 2014 and in 2015, and the King fire (2014) in 2015.

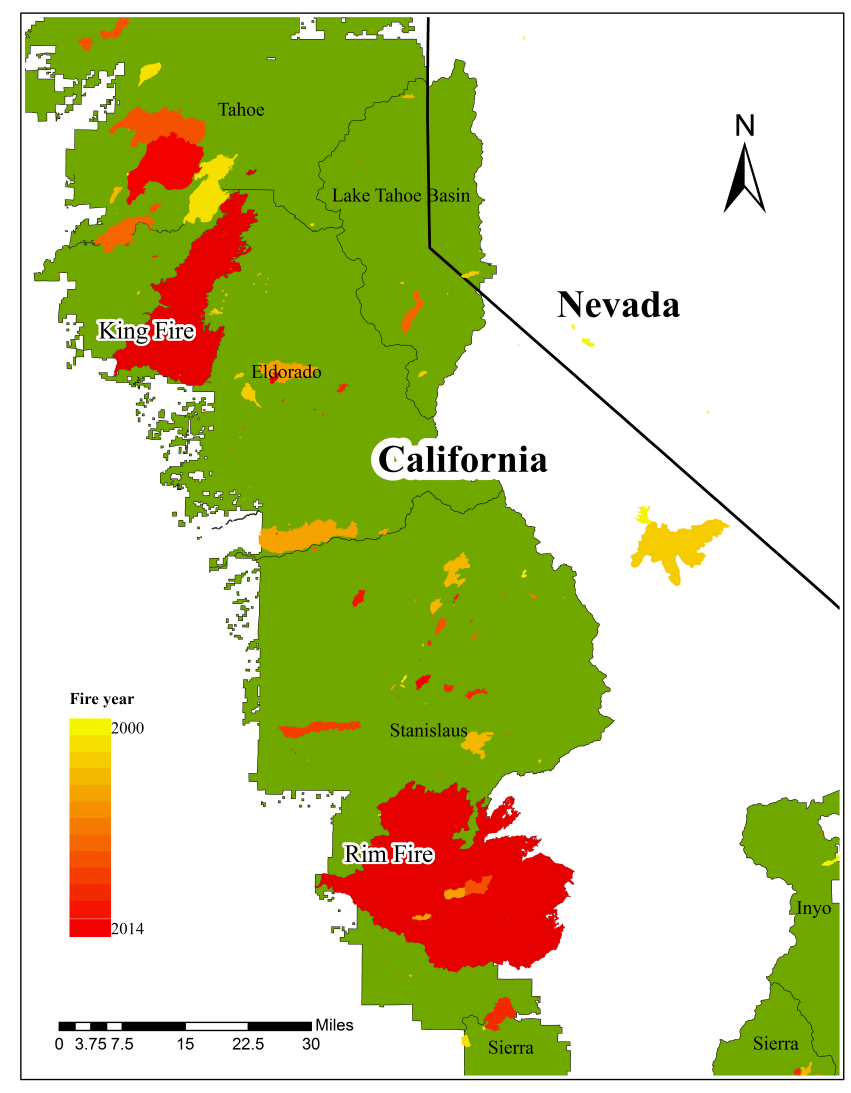


Fig. 2. Location of broadcast surveys (symbols that appear in black indicate positive detections) and nest searching transects within the Rim Fire. Broadcast surveys were conducted across forested lands managed by the US Forests Service (semitransparent areas indicate land not managed by the US Forest Service).

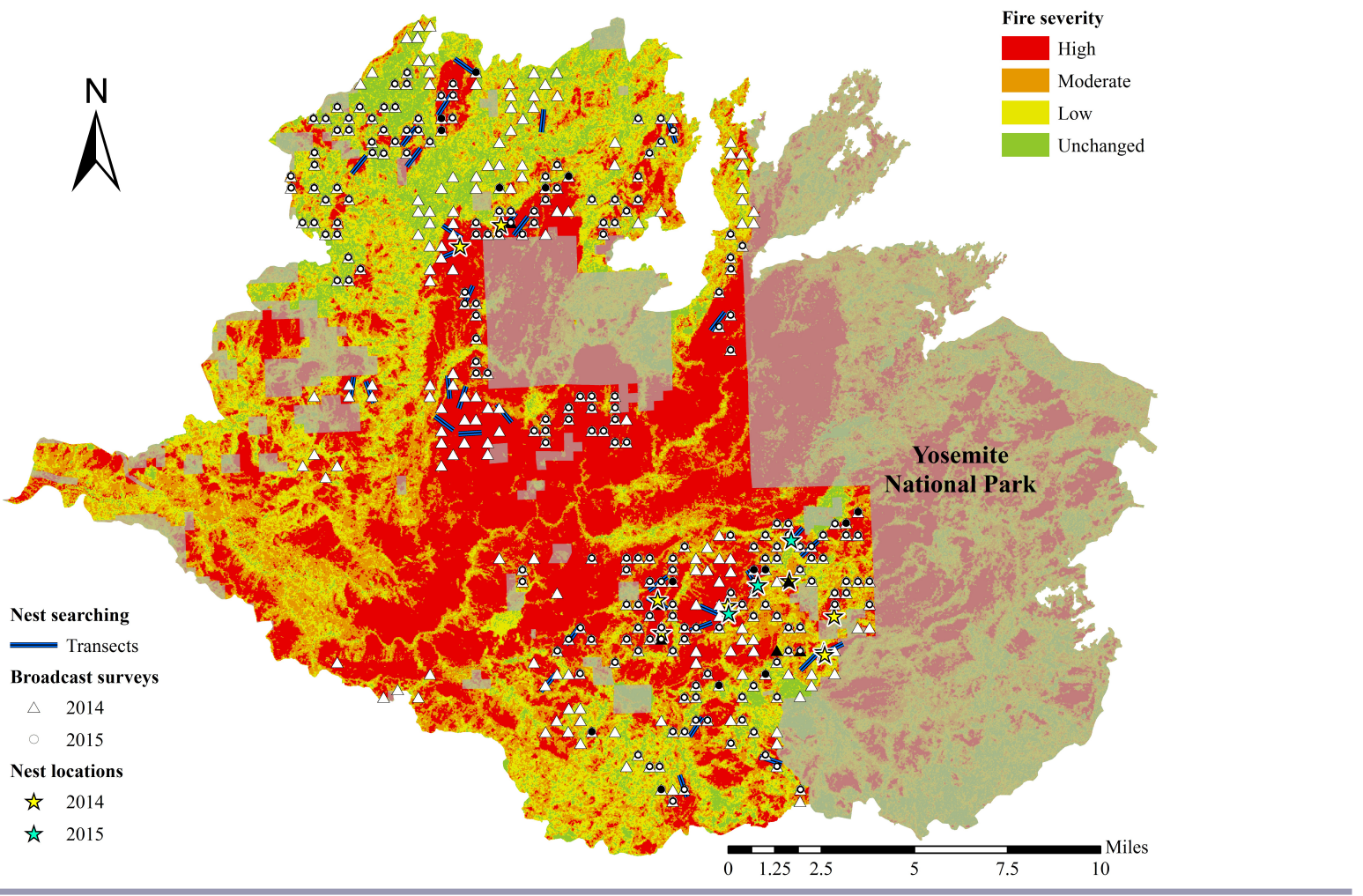

\section{Field surveys}

We surveyed for Black-backed Woodpeckers in May-August of 2014 (Rim fire) and 2015 (Rim and King fires), which spans the majority of the Black-backed Woodpecker breeding season (Tremblay et al. 2016). We stratified our surveys based on remotely sensed imagery of vegetation type and fire severity. We categorized fire severity using the Relative Normalized Burn Ratio (RdNBR), a measure of fire severity based on vegetation effects (Miller and Thode 2007). We assigned a fire severity class of unchanged, low, moderate, or high at the $30-\mathrm{m}$ pixel scale using RdNBR thresholds identified by Lydersen et al. (2016). We assigned a habitat type to each 30 -m pixel within the fire perimeter using the California Wildlife Habitat Relationships System (CWHR), which uses the composition of vegetation, the average size of trees, and canopy cover (Mayer and Laudenslayer 1988) to delineate important habitat for wildlife.

Because Black-backed Woodpeckers will use forests that burn at different severities (Tremblay et al. 2016), we conducted broadcast surveys across severity classes including 365 survey points in the Rim fire in 2014 (136 in areas that burned with low, 78 in moderate, and 151 in high severity), 220 survey points in the Rim fire in 2015, (74 low, 49 moderate, and 97 high severity), and 440 survey points in the King fire in 2015 (191 low, 67 moderate, and 182 high severity). We spaced individual survey points at least $500 \mathrm{~m}$ apart (Figs. 2 and 3). Black-backed Woodpeckers can be difficult to detect passively (Saracco et al. 2011) so we increased the probability of detecting individuals by broadcasting Blackbacked Woodpecker vocalizations (scream-rattle-snarl and kek calls) and territorial drumming sounds (recording by G. A. Keller, Macaulay Library of Natural Sounds, Cornell Laboratory of Ornithology). We played vocalizations for approximately $30 \mathrm{~s}$ followed by $90 \mathrm{~s}$ of listening and watching for a response, with the entire 2-min interval repeated 3 times. We broadcast recordings at a standardized volume using FOXPRO ZR2 digital game callers (FOXPRO Inc., Lewistown, Pensylvannia, USA). Using this protocol, Saracco et al. (2010) found that this methodology resulted in a $70 \%$ probability of detecting an individual if it was using the area. When a Black-backed Woodpecker was detected, we discontinued the broadcast survey and the observers attempted to follow the bird to its nest either immediately or during a repeat visit specifically for this purpose.

Broadcast surveys are frequently used to increase the chances of determining if a target species is nearby, but in soliciting a response and modifying behavior they can limit inferences as to how and at what scale the habitat is being utilized. To specifically address whether nesting behavior was influenced by the size and location of high-severity patches, we established 1-km, 200-m wide ( 20 ha) belt transects in areas more likely to be used for nesting by Black-backed Woodpeckers. Previous research in the 
Fig. 3. Location of broadcast surveys (symbols that appear in black indicate positive detections) and nest searching transects within the King Fire. Broadcast surveys were conducted across forested lands managed by the US Forests Service (semitransparent areas indicate land not operated by the US Forest Service).

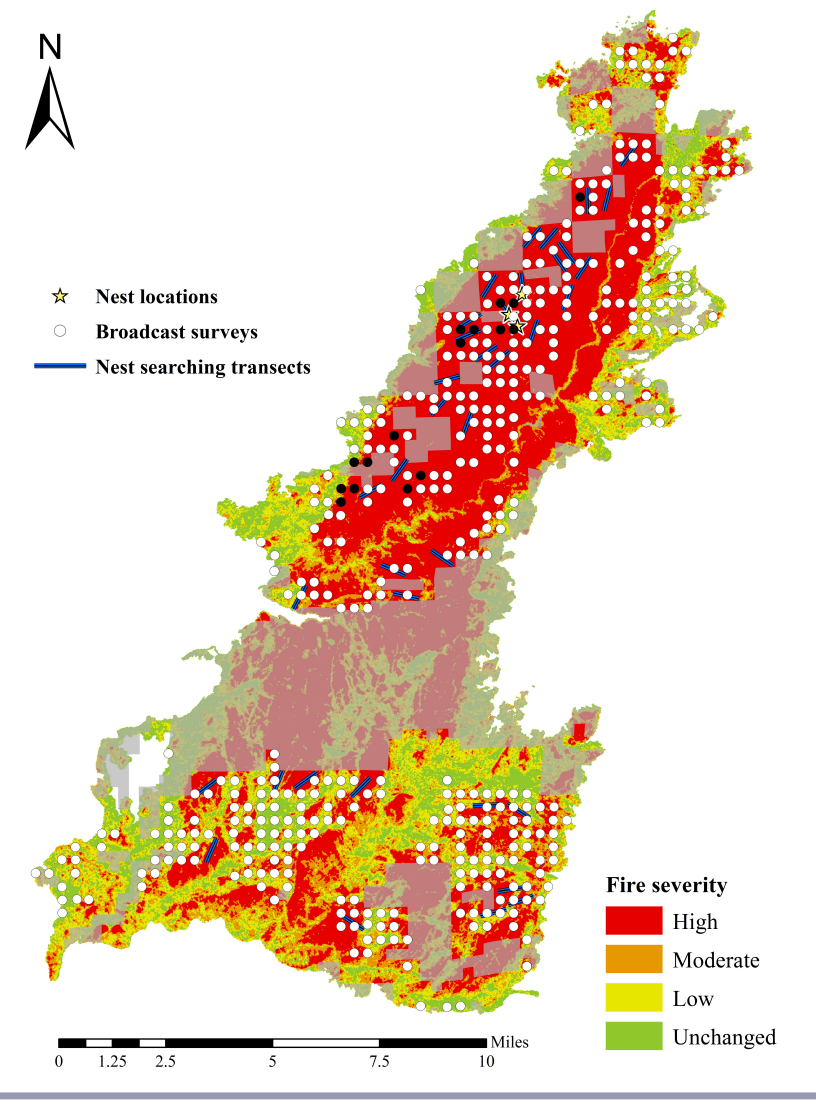

Sierra Nevada suggested that Black-backed Woodpeckers most commonly nest in dense patches of small- and medium-diameter snags (Seavy et al. 2012, Tarbill et al. 2015) and we targeted transects in CWHR classes that were most likely to represent these conditions (i.e., areas with an average tree diameter at breast height $>30 \mathrm{~cm}$ and average canopy cover $>40 \%$ that burned at high severity).

Trained observers surveyed these areas by slowly zigzagging across the belt transect on foot, spending a minimum of one hour on each transect. When a woodpecker was detected, it was followed until a nest was located or the bird moved out of sight. We searched a total of 68 transects in both fires; 34 in the Rim fire in 2014 and 34 in each of the Rim and King fires in 2015 (Figs. 2 and 3). We attempted to visit each transect two times per breeding season, with at least one week between visits. We rotated observers between visits to the same belt transect and reversed starting and ending points. Logistical and safety issues resulted in one transect at the Rim fire and five transects at the King fire being searched one time only.

\section{Data analysis}

We found few Black-backed Woodpecker nests, so we limited our statistical analysis to detection/nondetection of Black-backed Woodpeckers during broadcast surveys. We evaluated whether variation in several covariates explained positive detections of Black-backed Woodpeckers within the fire area using a generalized linear model with a logit link function. We implemented the model using a Bayesian analysis with Markov chain Monte Carlo (MCMC) in the R package rstanarm (Stan Development Team 2016). We specified the prior distribution of the regression coefficients using least absolute shrinkage and selection operator (lasso) and assumed our posterior distribution was binomial. We included covariates in our model that were uncorrelated and identified as important to Black-backed Woodpeckers in California including forest structure, elevation, and fire severity (Saracco et al. 2011, Fogg et al. 2014, Tingley et al. 2015). Distance to unburned forest may influence nest predation (Saab et al. 2011) and provide alternative habitat (Tingley et al. 2014, Stillman et al. 2019), therefore we also included the distance of the survey point to the outer fire perimeter, and the distance from the survey point to the nearest green patch ( $\geq 4$ ha of forest that was classified as unchanged or burned at low vegetation severity). These two distance variables allowed us to make inferences about the impacts of the size of high-severity patches and heterogeneity in fire effects on detections of Black-backed Woodpeckers. For this analysis, we categorized forest structure as dense conifer-dominated forest (conifer dominated CHWR vegetation types with an average tree diameter at breast height $>30 \mathrm{~cm}$ and average canopy cover $>$ $40 \%$ ), other forested CHWR habitats, and nonforested CHWR habitat. We calculated percent fire severity in our model as the percent of the surrounding forest (within $250 \mathrm{~m}$ of the broadcast point) that burned with high severity vegetation effects. Fire (Rim or King) and postfire survey year (postfire year 1 or 2) and their interaction were included as fixed effects. All covariates were standardized to have a mean of zero and a standard deviation of one. We ran two Markov chain Monte Carlo (MCMC) chains for 5000 iterations, saving alternate values. We discarded the first 500 samples so that values were saved once the chain reached equilibrium (i.e., burn-in). R-hat values were less than 1.1 for all parameters indicating the model had converged (Gelman and Hill 2006). We considered an effect of a covariate to be significant if the Bayesian credible interval of the coefficient (BCI; defined as the $2.5 \%$ and $97.5 \%$ quantiles of the posterior distribution) did not overlap zero.

\section{RESULTS}

We detected Black-backed Woodpeckers during seven $(<2 \%$ of survey points) broadcast surveys in the Rim fire in 2014 with the majority of detections occurring in habitat consistent with vegetation in the small number of locations in which we found nests (Table 1). In 2015, although we reduced the number of broadcast surveys in the Rim fire, we detected Black-backed Woodpeckers at 22 surveys (10\% of survey points), again predominately in habitat consistent with nest locations (Table 1). A similar percentage of detection occurred in areas that burned at low severity in 2014 ( 2 of 7) compared to 2014 ( 7 of 22). In the King fire, we detected Black-backed Woodpeckers at 18 (4\%) 
Table 1. The number of broadcast surveys conducted and Black-backed Woodpecker nests found in different forest types in the Rim and King fires. Number in parenthesis indicates survey points with detections during broadcast surveys. Forest type was defined according to the California Wildlife Habitat Relationships System, which uses the composition of vegetation, the average size of trees, and canopy cover (Mayer and Laudenslayer 1988).

\begin{tabular}{|c|c|c|c|c|c|c|}
\hline \multirow[b]{2}{*}{ Prefire Forest Stand Classification } & \multicolumn{2}{|c|}{$\operatorname{Rim} 2014$} & \multicolumn{2}{|c|}{$\operatorname{Rim} 2015$} & \multicolumn{2}{|c|}{ King 2015} \\
\hline & Surveys & Nests & Surveys & Nests & Surveys & Nests \\
\hline \multicolumn{7}{|l|}{ Sierra Mixed Conifer (SMC) } \\
\hline Trees $28-60 \mathrm{~cm} \mathrm{DBH},>60 \%$ canopy closure & $140(3)$ & 5 & $94(16)$ & 3 & $158(8)$ & 3 \\
\hline Trees $>60 \mathrm{~cm} \mathrm{DBH,}>60 \%$ canopy closure & $83(1)$ & 1 & $33(4)$ & 0 & $57(1)$ & 0 \\
\hline All other SMC combined & $36(1)$ & & $20(1)$ & 0 & $90(3)$ & 0 \\
\hline \multicolumn{7}{|l|}{ Ponderosa Pine (PPN) } \\
\hline Trees $28-60 \mathrm{~cm} \mathrm{DBH},>60 \%$ canopy closure & $46(1)$ & 0 & $37(0)$ & 0 & $30(2)$ & 0 \\
\hline Trees $>60 \mathrm{~cm} \mathrm{DBH},>60 \%$ canopy closure & $6(0)$ & 0 & $4(0)$ & 0 & $1(0)$ & 0 \\
\hline All other PPN combined & $37(0)$ & 0 & $25(0)$ & 0 & $30(2)$ & 0 \\
\hline \multicolumn{7}{|l|}{ Other forest types combined } \\
\hline Trees $28-60 \mathrm{~cm} \mathrm{DBH},>60 \%$ canopy closure & $7(1)$ & 1 & $4(0)$ & 0 & $25(1)$ & 0 \\
\hline Trees $>60 \mathrm{~cm} \mathrm{DBH},>60 \%$ canopy closure & $0(0)$ & 0 & $0(0)$ & 0 & $1(0)$ & 0 \\
\hline All other combined & $10(0)$ & 0 & $3(1)$ & 0 & $48(1)$ & 0 \\
\hline
\end{tabular}

Table 2. Mean estimates and posterior intervals of covariates on the logit scale from our generalized linear model explaining positive detections of Black-backed Woodpeckers at survey locations in the Rim and King fires. All covariates were standardized to have a mean of zero and a standard deviation of one. We provide descriptive statistics (mean and range) of survey conditions for continuous covariates.

\begin{tabular}{lcc}
\hline \hline Factor & $\begin{array}{c}\text { Parameter } \\
\text { estimate }\end{array}$ & Mean and range \\
\hline Intercept & $-3.6(-4.6,-2.8)$ & \\
Elevation (m) & $0.5(0.1,0.9)$ & $1433(726-2094)$ \\
High severity fire within $250 \mathrm{~m}$ & $0.5(0.2,0.9)$ & $0.34 \%(0 \%, 100 \%)$ \\
Distance to fire perimeter $(\mathrm{m})$ & $0.3(0.2,0.7)$ & $2820(1.5-7908.5)$ \\
Distance to unburned forest (m) & $-0.2(-0.6,0.1)$ & $240.8(0-2097.5)$ \\
Nonforest: Forest (other) & $-0.2(-1.9,0.8)$ & \\
Dense conifer: Forest (other) & $0.4(-0.2,1.3)$ & \\
Year & $0.2(-0.4,0.9)$ & \\
Rim:King & $0.0(-0.7,0.6)$ & \\
Year*Fire & $0.6(-0.1,1.3)$ & \\
\hline
\end{tabular}

survey locations, all but one of which burned at moderate to high severity. Despite the general consistency in habitat type between positive detection and nest locations, our model results did not provide statistical support for the classification of dense, conifer forest as influencing where Black-Backed Woodpeckers were detected (Table 2). Our model did provide statistical support for more detections of Black-backed Woodpeckers with increasing effects of percent of surrounding forest that burned at high severity, distance to the fire perimeter and elevation (Table 2; Fig. 4).

We located a total of 14 Black-backed Woodpecker nests across both fires and both years (Table 1). In 2014, we located eight Black-backed Woodpecker nests within the Rim fire, four of which we located while searching belt transects (Fig. 2), three we located by following an individual to its nest following a broadcast survey and one of which was reported by an independent party. Despite the increase in Black-backed Woodpecker detections in 2015 (Table 1), we only located three nests while searching belt transects and none during broadcast surveys. In the King fire in 2015, we located three nests during nest searching. We provided habitat characteristics attributed to each nest in Appendix 1. Due to the small sample size of nests found and logistical constraints we did few repeat visits to nests to determine how predicted variables may impact reproductive success and nestling survival. All nests found appeared to be active (Appendix 1) based on repeat visits to the nests by males and/or females and auditory cues.

Fig. 4. Bean plots illustrating the relationship between a) elevation, b) percent of high severity with $250 \mathrm{~m}$ of survey point, c) distance to fire perimeter, and d) distance to unburned forest and positive detections (circles) and nests (triangles) of Black-backed Woodpeckers in each year and location of the study. Each line represents a broadcast survey point with line length indicating the frequency.
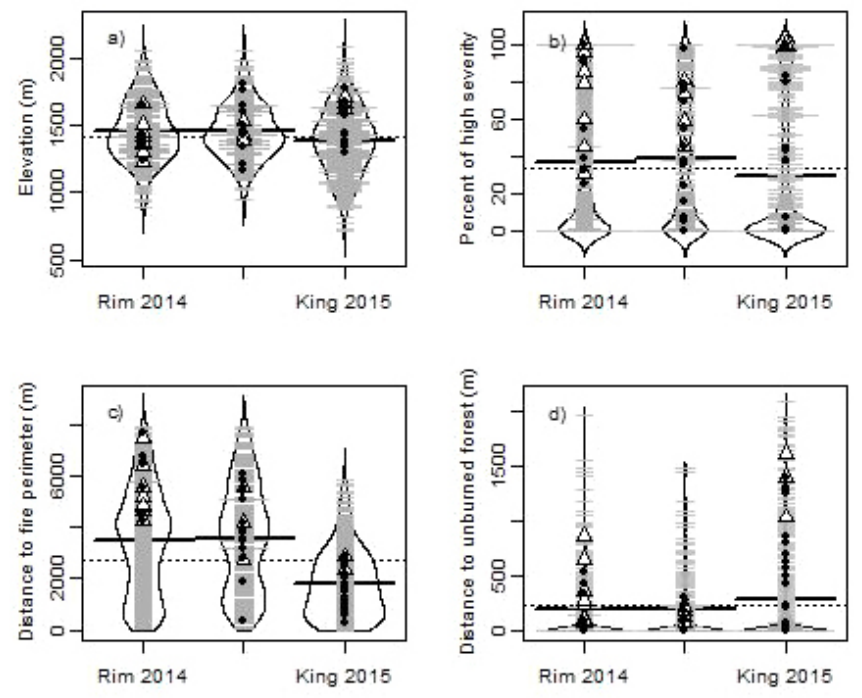
Table 3. Estimated densities of Black-backed Woodpeckers reported in fires in the Sierra Nevada relative to fire size, total hectares that burned at high severity, and total hectares of high severity that burned conifer and dense conifer vegetation (average tree $>61 \mathrm{~cm} \mathrm{DBH,}$ canopy closure $>40 \%$ ). Density estimates do not include standard errors and are provided for context.

\begin{tabular}{lccccccc}
\hline \hline Fire & Year & Fire size (ha) & High severity & Conifer & Dense conifer & $\begin{array}{c}\text { Density } \\
\text { (pairs per ha) }\end{array}$ & References \\
\hline Angora & 2007 & 1293 & 623 & 590 & 525 & 0.01 & Tarbill et al. 2010 \\
Barry Point & & 2012 & 16,410 & 5438 & 5223 & 3138 & 0.0094 \\
Chips & 2012 & 31,114 & 6794 & 6165 & 3760 & 0.0032 & Tingley et al. 2015 \\
King & 2014 & 39,640 & 18,259 & 12,599 & 8976 & $<0.0001^{\ddagger}$ & Tingley et al. 2015 al. 2015 \\
Reading & 2012 & 11,418 & 3844 & 3617 & 1280 & 0.0069 & Tingley et al. 2015 \\
Rim & 2013 & 104,460 & 30,970 & 14,905 & 11,048 & 0.0002 & Tingley et al. 2015 \\
\hline
\end{tabular}

Estimates include only the part of the fire that burned in California

* Based on calculations used in Tingley et al. (2015)

\section{DISCUSSION}

Despite surveying burned forest with conditions that tend to be positively associated with the presence of Black-backed Woodpeckers, we had few detections of this species in the Rim and King fires compared to other fires in the region (Table 3). Numerous studies throughout the range of the Black-backed Woodpecker indicate that it readily colonizes burned forest in the early years following fire, where it nests in dense stands of firekilled trees (Hutto 1995, Saab et al. 2007, Nappi and Drapeau 2009, Tarbill et al. 2015). Our detections of Black-backed Woodpeckers were consistent with these expectations and with other studies that support an effect of increasing elevation and fire severity on detections of Black-backed Woodpeckers (Saracco et al. 2011, Tingley et al. 2014). We did not mark individual birds, limiting our ability to estimate density, but broadcast surveys conducted in the second breeding season following the Rim fire resulted in more detections, but fewer nests, than in the previous year. Detection rates at survey sites may increase independently of abundance if individual birds are utilizing a larger area leading to detections of the same bird at multiple survey locations. Previous studies of radio-tagged individuals found that Black-backed Woodpecker home-range size increased with time since fire (Dudley and Saab 2007, Rota et al. 2014b) and with decreasing basal area of snags (Tingley et al. 2014) suggesting that larger home-range sizes are needed when resources are patchily distributed or habitat is generally of low quality. Taken together, our findings indicate that other factors including prey dynamics, natural variation in Black-backed Woodpecker populations, or behavioral constraints may have limited utilization of these fires.

The persistence of species at the metapopulation level depends on the extinction and colonization of habitat patches; the rate of which will be heavily influenced by patch size and inter-patch distances (Hanski 1998, Moilanen and Hanski 1998). In the case of Black-backed Woodpeckers, patch extinction is predetermined by the ephemeral nature of standing dead trees and the population dynamics of wood-boring beetles. Colonization rates are predicted to be higher with increasing patch size (but see Tingley et al. 2018) and decreasing inter-patch distances. Despite the large size of the fires, detections of Black-backed Woodpeckers in the Rim and King were low suggesting that the colonization of these fires may be limited by the number of available dispersers or interpatch distances (sensu Brotons et al. 2005). In a dynamic occupancy model of Black-backed Woodpeckers in the Sierra Nevada, Tingley et al. (2018) found that colonization of Blackbacked Woodpeckers within fires decreased with the size of fires at the fire-level (between-fire) and site-level (within-fire). In this study, however, we found no evidence that within-fire heterogeneity (measured as the distance to an unburned forest patch) had an effect on where Black-backed Woodpeckers were detected. Conversely, distance to fire perimeter had a positive effect on detection indicating that the large size of the fires per se did not have a negative influence on where birds were detected. In addition, anecdotal evidence does not suggest that colonization was limited by the number of dispersing individuals because Black-backed Woodpeckers occur at lower densities in unburned forest (Fogg et al. 2014) and both the Rim and King fires burned well within the dispersal distance of several older fires with known reproductive populations of Black-backed Woodpeckers (Fig. 1).

A lack of their preferred prey item, wood-boring beetle larvae, may decrease habitat suitability for Black-backed Woodpeckers (Bonnot et al. 2008, Nappi et al. 2010, Rota et al. 2014a). Many species of wood-boring beetles have specific physiological adaptations for detecting fire events, such as pit-sensing organs that allow them to detect infrared radiation emitted during forest fire, or antenna that can detect smoke from as far as $50 \mathrm{~km}$ (Schmitz and Bleckmann 1998, Schütz et al. 1999). These adaptations allow adult wood-borers to quickly find burned tress in which to lay their eggs, where they will hatch into larvae that develop in the wood of the tree. Costello et al. (2011) surveyed wildfires in ponderosa pine forests one to three years after burning and found that more than half of the dead trees were colonized with wood-boring larvae. Both the Rim and King fires burned relatively late in the season (August/September), and Tingley et al. (2018) speculated that later ignition dates may alter the abundance and species of insects able to colonize the fire. Supporting this, we found that fires igniting later in the fire season supported lower rates of larval woodborer activity (Ray et al. 2019). However, Tingley et al. (2018) found that colonization by Black-backed Woodpeckers was positively associated with later ignition dates possibly leading to asynchronous timing between colonization of fires by predators and their prey.

Fires in the Sierra Nevada, and much of western North America, are predicted to continue to increase in size and severity over a longer fire season to become larger because of changes in forest density and climatic conditions (Westerling et al. 2006, van 
Mantgem et al. 2013). Although fire has been the dominant force shaping forest structure and wildlife communities in this region, the size and intensity of recent fires is generally described as outside the historic range of variation (Westerling et al. 2006, Dennison et al. 2014), and may have impacts on species that evolved under a different disturbance regime. However, in this study we did not find that the size and severity of contemporary fires necessarily posed a problem for Black-backed Woodpeckers. In a comprehensive study by Tingley et al. (2018), they concluded that although fire size does not affect colonization rates, larger fires do have lower woodpecker densities. Lower densities of Black-backed Woodpeckers in contemporary fires may in part be explained by age-structured habitat requirements (Stillman et al. 2019) that necessitate a mosaic of burn conditions. Alternatively, the later timing of the Rim and King fire may have indirectly affected Black-backed Woodpecker densities by limiting the colonization of their prey (Ray et al. 2019). A better understanding of the factors that govern population dynamics of Black-backed Woodpecker and other irruptive species will help predict their resilience to changing environments.

Responses to this article can be read online at: http://www.ace-eco.org/issues/responses.php/1375

\section{Acknowledgments:}

We thank our dedicated field technicians, particularly Matt Lerow, Heather Mackey, and Lynn Schofield who led our field crews and were instrumental in the success of the project. Alyssa Fellow and Jen House of the Eldorado National Forest, Vern Shumway of the Stanislaus National Forest, and Tray Biasiolli of the Pacific Southwest Research Station provided much needed logistical support. Chrissy Howell provided logistical support and constructive feedback that improved the quality of this research. Richard Hutto and Junior Tremblay provided useful comments of earlier versions of this manuscript. Funding was provided by USFS Region 5, the Eldorado National Forest, and the Pacific Southwest Research Station. The use of trade, product, or firm names is for descriptive purposes only and does not imply endorsement by the US Government.

\section{LITERATURE CITED}

Adams, M. A. 2013. Mega-fires, tipping points and ecosystem services: managing forests and woodlands in an uncertain future. Forest Ecology and Management 294:250-261. https://doi. org/10.1016/j.foreco.2012.11.039

Bonnot, T. W., M. A. Rumble, and J. J. Millspaugh. 2008. Nest success of Black-backed Woodpeckers in forests with mountain pine beetle outbreaks in the Black Hills, South Dakota. Condor 110:450-457. https://doi.org/10.1525/cond.2008.8460

Brotons, L., P. Pons, and S. Herrando. 2005. Colonization of dynamic Mediterranean landscapes: where do birds come from after fire? Journal of Biogeography 32:789-798. https://doi. org/10.1111/j.1365-2699.2004.01195.x
Costello, S. L., J. F. Negrón, and W. R. Jacobi. 2011. Wood-boring insect abundance in fire-injured ponderosa pine. Agricultural and Forest Entomology 13:373-381. https://doi.org/10.1111/ j.1461-9563.2011.00531.x

Dennison, P. E., S. C. Brewer, J. D. Arnold, and M. A. Moritz. 2014. Large wildfire trends in the western United States, 1984-2011. Geophysical Research Letters 41:2928-2933. https:// doi.org/10.1002/2014GL059576

Dudley, J. G., and V. A. Saab. 2007. Home range size of Blackbacked Woodpeckers in burned forests of southwestern Idaho. Western North American Naturalist 67:593-600. [online] URL: https://www.fs.fed.us/rm/pubs_other/rmrs_2007_dudley_j001.pdf

Fogg, A. M., L. J. Roberts, and R. D. Burnett. 2014. Occurrence patterns of Black-backed Woodpeckers in green forest of the Sierra Nevada Mountains, California, USA. Avian Conservation and Ecology 9(2):3. https://doi.org/10.5751/ACE-00671-090203

Gelman, A., and J. Hill. 2006. Data analysis using regression and multilevel/hierarchical models. Cambridge University Press, New York, New York, USA. https://doi.org/10.1017/CBO9780511790942

Hanski, I. 1998. Metapopulation ecology. Oxford University Press, Oxford, UK.

Hutto, R. L. 1995. Composition of bird communities following stand-replacement fires in Northern Rocky Mountain (U.S.A.) conifer forests. Conservation Biology 9:1041-1058. https://doi. org/10.1046/j.1523-1739.1995.9051033.x-i1

Hutto, R. L. 2006. Toward meaningful snag-management guidelines for postfire salvage logging in North American conifer forests. Conservation Biology 20:984-993. https://doi.org/10.1111/ j.1523-1739.2006.00494.X

Hutto, R. L. 2008. The ecological importance of severe wildfires: some like it hot. Ecological Applications 18:1827-1834. https://doi. org/10.1890/08-0895.1

Jones, G. M., R. J. Gutiérrez, D. J. Tempel, S. A. Whitmore, W. J. Berigan, and M. Z. Peery. 2016. Megafires: an emerging threat to old-forest species. Frontiers in Ecology and the Environment 14:300-306. https://doi.org/10.1002/fee.1298

Long, J. W., C. N. Skinner, M. North, C. T. Hunsaker, and L. Quinn-Davidson. 2014. Integrative approaches: promoting socioecological resilience. Pages 17-54 in J. W. Long, L. QuinnDavidson, and C. N. Skinner, editors. Science synthesis to support sociological resilience in the Sierra Nevada and Southern Cascade Range. USDA Forest Service, Pacific Southwest Research Station, Albany, California, USA. [online] URL: https://www.fs. fed.us/psw/publications/documents/psw_gtr247/chapters/ psw_gtr247_chapter1_2.pdf

Lydersen, J. M., M. P. North, and B. M. Collins. 2014. Severity of an uncharacteristically large wildfire, the Rim Fire, in forests with relatively restored frequent fire regimes. Forest Ecology and Management 328:326-334. https://doi.org/10.1016/j.foreco.2014.06.005

Mayer, K. E., and W. F. Laudenslayer, Jr. 1988. A guide to wildlife habitats of California. State of California, Resources Agency, Department of Fish and Game, Sacramento, California, USA. [online] URL: https://www.wildlife.ca.gov/Data/CWHR/WildlifeHabitats 
Miller, J. D., H. D. Safford, M. Crimmins, and A. E. Thode. 2009. Quantitative evidence for increasing forest fire severity in the Sierra Nevada and southern Cascade Mountains, California and Nevada, USA. Ecosystems 12:16-32. https://doi.org/10.2307/176839

Miller, J. D., and A. E. Thode. 2007. Quantifying burn severity in a heterogeneous landscape with a relative version of the delta Normalized Burn Ratio (dNBR). Remote Sensing of Environment 109:66-80. https://doi.org/10.1016/j.rse.2006.12.006

Moilanen, A., and I. Hanski. 1998. Metapopulation dynamics: effects of habitat quality and landscape structure. Ecology 79:2503-2515. https://doi.org/10.2307/176839

Murphy, E. C., and W. A. Lehnhausen. 1998. Density and foraging ecology of woodpeckers following a stand-replacement fire. Journal of Wildlife Management 62:1359-1372. https://doi. org/10.2307/3802002

Nappi, A., and P. Drapeau. 2009. Reproductive success of the Black-backed Woodpecker (Picoides arcticus) in burned boreal forests: are burns source habitats? Biological Conservation 142:1381-1391. https://doi.org/10.1016/j.biocon.2009.01.022

Nappi, A., P. Drapeau, J.-F. Giroux, and J.-P. L. Savard. 2003. Snag use by foraging Black-backed Woodpeckers (Picoides articus) in recently burned eastern boreal forest. Auk 120:505-511.

Nappi, A., P. Drapeau, M. Saint-Germain, and V. A. Angers. 2010. Effect of fire severity on long-term occupancy of burned boreal conifer forests by saproxylic insects and wood-foraging birds. International Journal of Wildland Fire 19:500-511. https:// doi.org/10.1071/WF08109

North, M., B. M. Collins, and S. Stephens. 2012. Using fire to increase the scale, benefits, and future maintenance of fuels treatments. Journal of Forestry 110:392-401. https://doi. org/10.5849/jof.12-021

Payette, S. 1992. Fire as a controlling process in the North American boreal forest. Pages 144-169 in H. H. Shugart, R. Leemans, and G. B. Bonan, editors. A systems analysis of the global boreal forest. Cambridge University Press, Cambridge, Massachusetts, USA. https://doi.org/10.1017/CBO9780511565489.006

Raphael, M. G., and M. White. 1984. Use of snags by cavitynesting birds in the Sierra Nevada. Wildlife Monographs 86:3-66.

Ray, C., D. R. Cluck, R L. Wilkerson, R. B. Siegel, A. M. White, G. L. Tarbill, S. C. Sawyer, and C. A. Howell. 2019. Patterns of woodboring beetle activity following fires and bark beetle outbreaks in montane forests of California. Fire Ecology, in press.

Rota, C. T., J. J. Millspaugh, M. A. Rumble, C. P. Lehman, and D. C. Kesler. 2014a. The role of wildfire, prescribed fire, and mountain pine beetle infestations on the population dynamics of Black-Backed Woodpeckers in the Black Hills, South Dakota. PLoS ONE 9:e94700. https://doi.org/10.1371/journal.pone.0094700

Rota, C. T., M. A. Rumble, J. J. Millspaugh, C. P. Lehman, and D. C. Kesler. 2014b. Space-use and habitat associations of Blackbacked Woodpeckers (Picoides arcticus) occupying recently disturbed forests in the Black Hills, South Dakota. Forest Ecology and Management 313:161-168. https://doi.org/10.1016/j.

foreco.2013.10.048
Saab, V. A., and H. D. W. Powell. 2005. Fire and avian ecology in North America: process influencing pattern. Studies in Avian Biology 30:1-13. [online] URL: https://sora.unm.edu/sites/ default/files/journals/sab/sab_030.pdf

Saab, V. A., R. E. Russell, and J. G. Dudley. 2007. Nest densities of cavity-nesting birds in relation to postfire salvage logging and time since wildfire. Condor 109:97-108.

Saab, V. A., R. E. Russell, J. Rotella, and J. G. Dudley. 2011. Modeling nest survival of cavity-nesting birds in relation to postfire salvage logging. Journal of Wildlife Management 75:794-804. https://doi.org/10.1002/jwmg.111

Safford, H. D., and J. T. Stevens. 2017. Natural range of variation for yellow pine and mixed-conifer forests in the Sierra Nevada, southern Cascades, and Modoc and Inyo National Forests, California, USA. US Department of Agriculture, Forest Service, Pacific Southwest Research Station, Albany, California, USA. [online] URL: https://www.fs.fed.us/psw/publications/documents/ psw_gtr256/psw_gtr256.pdf

Saracco, J. F., R. B. Siegel, and R. L. Wilkerson. 2011. Occupancy modeling of Black-backed Woodpeckers on burned Sierra Nevada forests. Ecosphere 2:1-17. https://doi.org/10.1890/ ES10-00132.1

Schmitz, H., and H. Bleckmann. 1998. The photomechanic infrared receptor for the detection of forest fires in the beetle Melanophila acuminata (Coleoptera: Buprestidae). Journal of Comparative Physiology A 182:647-657. https://doi.org/10.1007/ s003590050210

Schütz, S., B. Weissbecker, H. E. Hummel, K.-H. Apel, H. Schmitz, and H. Bleckmann. 1999. Insect antenna as a smoke detector. Nature 398:298-299. https://doi.org/10.1038/18585

Seavy, N. E., R. D. Burnett, and P. J. Taille. 2012. Black-backed Woodpecker nest-tree preference in burned forests of the Sierra Nevada, California. Wildlife Society Bulletin 36:722-728. https:// doi.org/10.1002/wsb.210

Siegel, R. B., M. L. Bond, C. A. Howell, S. C. Sawyer, and D. L. Craig. 2018. A conservation strategy for the Black-backed Woodpecker (Picoides arcticus) in California. Version 2.0. Institute for Bird Populations and California Partners in Flight, Point Reyes Station, California, USA. [online] URL: https://www. birdpop.org/docs/pubs/Siegel_et_al_2018_BBWO_Cons_Strat_V2. pdf

Stan Development Team. 2016. rstanarm: Bayesian applied regression modeling via Stan. $\mathrm{R}$ package version 2.13 .1 . $\mathrm{R}$ Development Team, Vienna, Austria. [online] URL: http://mcstan.org/

Steel, Z. L., M. J. Koontz, and H. D. Safford. 2018. The changing landscape of wildfire: burn pattern trends and implications for California's yellow pine and mixed conifer forests. Landscape Ecology 33:1159-1176. https://doi.org/10.1007/s10980-018-0665-5

Steel, Z. L., H. D. Safford, and J. H. Viers. 2015. The fire frequency-severity relationship and the legacy of fire suppression in California forests. Ecosphere 6:1-23. https://doi.org/10.1890/ ES14-00224.1

Stephens, S. L., N. Burrows, A. Buyantuyev, R. W. Gray, R. E. 
Keane, R. Kubian, S. Liu, F. Seijo, L. Shu, K. G. Tolhurst, and J. W. van Wagtendonk. 2014. Temperate and boreal forest megafires: characteristics and challenges. Frontiers in Ecology and the Environment 12:115-122. https://doi.org/10.1890/120332

Stevens, J. T., B. M. Collins, J. D. Miller, M. P. North, and S. L. Stephens. 2017. Changing spatial patterns of stand-replacing fire in California conifer forests. Forest Ecology and Management 406:28-36. https://doi.org/10.1016/j.foreco.2017.08.051

Stillman, A. N., R. B. Siegel, R. L. Wilkerson, M. Johnson, and M. W. Tingley. 2019. Age-dependent habitat relationships of a burned forest specialist emphasise the role of pyrodiversity in fire management. Journal of Applied Ecology 56:880-890. https://doi. org/10.1111/1365-2664.13328

Tarbill, G. L., P. N. Manley, and A. M. White. 2015. Drill, baby, drill: the influence of woodpeckers on post-fire vertebrate communities through cavity excavation. Journal of Zoology 296:95-103. https://doi.org/10.1111/jzo.12220

Tingley, M. W., A. N. Stillman, R. L. Wilkerson, C. A. Howell, S. C. Sawyer, and R. B. Siegel. 2018. Cross-scale occupancy dynamics of a postfire specialist in response to variation across a fire regime. Journal of Animal Ecology 87:1484-1496. https://doi. org/10.1111/1365-2656.12851

Tingley, M. W., R. L. Wilkerson, M. L. Bond, C. A. Howell, and R. B. Siegel. 2014. Variation in home-range size of Black-backed Woodpeckers. Condor 116:325-340. https://doi.org/10.1650/ CONDOR-13-140.1

Tingley, M. W., R. L. Wilkerson, C. A. Howell, and R. B. Siegel. 2016. An integrated occupancy and space-use model to predict abundance of imperfectly detected, territorial vertebrates. Methods in Ecology and Evolution 7:508-517. https://doi. org/10.1111/2041-210X.12500

Tremblay, J. A., R. D. Dixon, V. A. Saab, P. Pyle, and M. A. Patten. 2016. Black-backed Woodpecker (Picoides arcticus). In P. G. Rodewald, editor. The Birds of North America. Version 3.0 edition. Cornell Lab of Ornithology, Ithaca, New York, USA. https://doi.org/10.2173/bna.bkbwoo.03

Tremblay, J. A., J. Ibarzabal, and J.-P. L. Savard. 2010. Foraging ecology of Black-backed Woodpeckers (Picoides arcticus) in unburned eastern boreal forest stands. Canadian Journal of Forest Research 40:991-999. https://doi.org/10.1139/X10-044

van Mantgem, P. J., J. C. B. Nesmith, M. Keifer, E. E. Knapp, A. Flint, and L. Flint. 2013. Climatic stress increases forest fire severity across the western United States. Ecology Letters 16:1151-1156. https://doi.org/10.1111/ele.12151

Villard, P. 1994. Foraging behavior of Black-backed and Threetoed woodpeckers during spring and summer in a Canadian boreal forest. Canadian Journal of Zoology 72:1957-1959. https:// doi.org/10.1139/z94-266
Westerling, A. L., H. G. Hidalgo, D. R. Cayan, and T. W. Swetnam. 2006. Warming and earlier spring increase western U. S. forest wildfire activity. Science 313:940-943. https://doi. org/10.1126/science. 1128834

Williams, J. 2013. Exploring the onset of high-impact mega-fires through a forest land management prism. Forest Ecology and Management 294:4-10. https://doi.org/10.1016/j.foreco.2012.06.030
Editor-in-Chief: Keith A.Hobson Subject Editor: Jean-Pierre L.Savard
Sponsored by the Society of Canadian Ornithologists and Bird Studies Canada Parrainée par la Société des ornithologistes $d u$ Canada et Études d'oiseaux Canada 
Appendix 1. Appendix 1. Characteristics of black-back woodpecker nests found in this study. Density estimates provided are stems per hectare. All nest were excavated in newly fire-killed trees.

Please click here to download file 'appendix1.xls'. 